\title{
Occurrence of Amyotrophic Lateral Sclerosis in Type 1 Gaucher Disease
}

Lais M. Oliveira, MD,* Tara Rastin, MD,* Graeme A.M. Nimmo, MBBS, MSc, Jay P. Ross, BSc, Patrick A. Dion, PhD, Ming Zhang, PhD, Dayna-Lynn Nevay, MSc, CCGC, David Arkadir, MD, PhD, Marc Gotkine, MBBS, Carolina Barnett, MD, PhD, Christen L. Shoesmith, MD, Ari Zimran, MD, Ekaterina A. Rogaeva, PhD, Lorne Zinman, MD, MSc, Guy A. Rouleau, MD, PhD, Ziv Gan-Or, MD, PhD, Dominick Amato, MD, and Lorraine V. Kalia, MD, PhD

Neurol Genet 2021;7:e600. doi:10.1212/NXG.0000000000000600

\section{Abstract}

\section{Objective}

To report the association between type 1 Gaucher disease (GD1) and amyotrophic lateral sclerosis (ALS) in 3 unrelated families and to explore whether GBA variants influence the risk of ALS.

\section{Methods}

We conducted retrospective chart reviews of patients with GD1 or their family members diagnosed with ALS. To further investigate whether there is an association between ALS and GD, we performed exploratory analyses for the presence of GBA variants in 3 ALS cohorts from Toronto (Canada), Montreal (Canada), and Project MinE (international), totaling 4,653 patients with ALS and 1,832 controls.

\section{Results}

We describe 2 patients with GD1 and 1 obligate GBA mutation carrier (mother of GD1 patient) with ALS. We identified 0 and 8 GBA carriers in the Toronto and Montreal cohorts, respectively. The frequencies of GBA variants in patients with ALS in the Montreal and Project MinE cohorts were similar to those of Project MinE controls or Genome Aggregation Database population controls.

\section{Conclusions}

The occurrence of ALS in biallelic or monoallelic GBA mutation carriers described here, in addition to common pathogenic pathways shared by GD1 and ALS, suggests that GBA variants could influence ALS risk. However, analyses of GBA variants in ALS cohorts did not reveal a meaningful association. Examination of larger cohorts and neuropathologic studies will be required to elucidate whether patients with GD1 are indeed at increased risk for ALS.

\author{
Correspondence \\ Dr. Kalia \\ lorraine.kalia@utoronto.ca
}

*These authors contributed equally to this work (i.e., they are co-first authors).

From the Krembil Research Institute (L.M.O., L.V.K.), Toronto Western Hospital, University Health Network, Ontario; Djavad Mowafaghian Centre for Brain Health (T.R.), Division of Neurology, Department of Medicine, University of British Columbia, Vancouver; Mark Feedman and Judy Jacobs Program for Gaucher Disease (G.A.M.N., D. Amato, L.V.K.), Mount Sinai Hospital; Fred A. Litwin Family Centre for Genetic Medicine (G.A.M.N., D.-L.N.), Department of Medicine, Mount Sinai Hospital and Toronto General Hospital, University Health Network, University of Toronto, Ontario; Department of Human Genetics (J.P.R., P.A.D., G.A.R., Z.G.-O.), Montreal Neurological Institute and Hospital (.P.R., P.A.D., G.A.R., Z.G.-O.), and Department of Neurology and Neurosurgery (P.A.D., G.A.R., Z.G.-O.), McGill University, Quebec; Tanz Centre for Research in Neurodegenerative Diseases (M.Z., E.A.R., L.V.K.), University of Toronto, Ontario, Canada; Shanghai First Rehabilitation Hospital (M.Z.), School of Medicine, Clinical Center for Brain and Spinal Cord Research (M.Z.), and Institute for Advanced Study (M.Z.), Tongji University, Shanghai, China; Department of Neurology (D. Arkadir, M.G.), Hadassah Medical Center, Hebrew University, Jerusalem, Israel; Ellen and Martin Prosserman Centre for Neuromuscular Diseases (C.B.), Division of Neurology, Department of Medicine, Toronto General Hospital, University Health Network, University of Toronto; London Health Sciences Centre (C.L.S.), London, Ontario, Canada; Gaucher Unit (A.Z.), Shaare Zedek Medical Center, Hadassah Medical School, Hebrew University, Jerusalem, Israel; Division of Neurology (L.Z.), Department of Medicine, Sunnybrook Health Sciences Centre, University of Toronto; and Edmond J. Safra Program in Parkinson's Disease and the Morton and Gloria Shulman Movement Disorders Clinic (L.V.K.), Division of Neurology, Department of Medicine, Toronto Western Hospital, University Health Network, University of Toronto, Ontario, Canada. 


\section{Glossary}

AF = allele frequency; ALP = autophagy-lysosomal pathway; ALS = amyotrophic lateral sclerosis; DLB = dementia with Lewy bodies; GD = Gaucher disease; GD1 = type 1 GD; gnomAD = Genome Aggregation Database; LSD = lysosomal storage disorder; $\mathbf{M N D}=$ motor neuron disease; PD = Parkinson disease; WES = whole-exome sequencing; WGS = whole-genome sequencing.

Gaucher disease (GD) is a lysosomal storage disorder (LSD) caused by biallelic mutations in the GBA gene. GBA variants are also important risk factors for synucleinopathies, specifically Parkinson disease (PD) and dementia with Lewy bodies (DLB). ${ }^{1}$ Of interest, other LSD-related genes have been implicated in neurodegeneration. For instance, SMPD1 variants were recently associated with risk of $\mathrm{PD} .^{2}$ Although multiple pathways are involved in PD pathogenesis, the main mechanism thought to underlie the association between LSD and PD is dysfunction in the autophagy-lysosomal pathway (ALP). ${ }^{3}$

Amyotrophic lateral sclerosis (ALS) is a motor neuron disease (MND) that also likely results from several pathogenic mechanisms, including ALP dysfunction. ${ }^{4}$ Recent case reports of patients diagnosed with both ALS and a LSD, such as Fabry disease or type $3 \mathrm{GD},{ }^{5,6}$ raise the possibility that common lysosomal abnormalities may underlie the co-occurrence of these disorders. The aims of this study are (1) to report the association between type 1 GD (GD1) and ALS in 3 unrelated families and (2) to explore whether GBA variants increase the risk of developing ALS.

\section{Methods}

\section{Patients}

Fifty-six patients with GD1 from the Mark Freedman \& Judy Jacobs Program for Gaucher Disease at Mount Sinai Hospital (Toronto, Canada) underwent routine assessment by a neurologist (L.V.K.) between 2017 and 2020. One patient was diagnosed with ALS (case 1), and 1 patient had a first-degree relative with ALS (case 3). One GD1 patient with probable ALS (case 2) was identified at a medical center in Israel.

\section{Genetic Analyses}

We examined for GBA variants in 3 ALS cohorts: (1) 125 patients with ALS from Sunnybrook Health Sciences Centre (Toronto, Canada) who underwent whole-genome sequencing (WGS) at Genome Quebec (Montreal, Canada); (2) 162 French-Canadian patients with ALS who underwent whole-exome sequencing (WES) at the Montreal Neurological Institute (Montreal, Canada); and (3) 4,366 patients with ALS and 1,832 age- and sexmatched controls from the international Project MinE WGS data set. $^{7,8}$ Only exons $1-9$ were analyzed; exons 10 and 11 were not analyzed due to similarities to the pseudo-GBA gene and limitations regarding reliability of WGS or WES findings in these exons. Only nonsynonymous and loss-of-function GBA variants were analyzed. We used the legacy glucocerebrosidase protein sequence nomenclature to describe the variants. For details, see e-Methods (links.lww.com/NXG/A428).

\section{Standard Protocol Approvals, Registrations, and Patient Consents}

Informed consent was obtained from case 1 and next of kin of case 3. Relatives of case 2 were not contactable, and thus, the case description was anonymized. Retrospective review of clinical data was conducted in accordance with the Helsinki Declaration. Informed consent for participation in the genetic study was obtained from the Toronto participants in accordance with the University of Toronto research ethics board (protocol \#34754) and from the French-Canadian Montreal participants in accordance with the Montreal Neurological Institute and Hospital research ethics board (approval \#20172740), affiliated with the McGill University Health Centre research ethics board.

\section{Data Availability}

All data relevant from case 1, case 3, and Project MinE are included in the article or uploaded as supplementary information. Anonymized data from case 2 may be shared by request from any qualified investigator.

\section{Results}

\section{Patients}

Case 1 was diagnosed with clinically probable laboratorysupported ALS. Case 2 presented with probable ALS, but ultimately developed clinically definite ALS. Case 3 was an obligate GBA mutation carrier who was also diagnosed with ALS. She was the mother of a patient with GD1 with PD. Clinical data and genetic investigations are described in table 1, figure e-1 and e-Results (links.lww.com/NXG/A428).

\section{ALS Cohorts}

We did not identify any patients with ALS with a GBA variant by WGS in the Toronto cohort. Eight patients in the FrenchCanadian ALS cohort were found to have one of the following GBA variants: E326K, T369M, N370S, and S52L (table 2). In 2 cases, there was a variant of uncertain significance in an ALSrelated gene: (1) CCNF H69Y variant in a GBA T369M carrier and (2) DCTN1 G467A variant in a GBA E326K carrier. The frequency of GBA variants in the FrenchCanadian ALS cohort was similar to that of European population controls in the Genome Aggregation Database (gno$\mathrm{mAD}$ ) database. Thirty-five GBA variants were identified in patients with ALS or controls from the Project MinE data set and were rare (table 3). The frequency of these GBA variants in ALS patients was similar to that of Project MinE or gno$\mathrm{mAD}$ population controls. 
Table 1 GBA Patients With ALS

\begin{tabular}{|c|c|c|c|}
\hline & Case 1 & Case 2 & Case 3 \\
\hline Age & 52 & Mid-50s & 70 \\
\hline $\begin{array}{l}\text { MND signs } \\
\text { and } \\
\text { symptoms }\end{array}$ & $\begin{array}{l}\text { Falls and muscle cramps, muscle flickering, } \\
\text { limb weakness, and slurred speech }\end{array}$ & Dysarthria & $\begin{array}{l}\text { Exhaustion, respiratory symptoms, UE and } \\
\text { proximal LE weakness, and muscle } \\
\text { twitches }\end{array}$ \\
\hline GD diagnosis & GD1 diagnosed at age 2 & GD1 diagnosed during preschool years & Daughter diagnosed with GD1 \\
\hline $\begin{array}{l}\text { GD-related } \\
\text { features }\end{array}$ & $\begin{array}{l}\text { Splenomegaly, thrombocytopenia, fatigue, } \\
\text { and recurrent upper respiratory infections }\end{array}$ & $\begin{array}{l}\text { Hepatosplenomegaly, thrombocytopenia, } \\
\text { life-threatening postpartum bleeding, and } \\
\text { anemia. Secondary Ortner syndrome. }\end{array}$ & None \\
\hline $\begin{array}{l}\text { GBA gene } \\
\text { mutation }\end{array}$ & Compound heterozygous N370S/W378G & Compound heterozygous N370S/c.84dupG & $\begin{array}{l}\text { NA (presumed obligate GBA carrier of } \\
\text { N370S or P236T) }\end{array}$ \\
\hline GD therapy & Velaglucerase alfa & Imiglucerase & None \\
\hline $\begin{array}{l}\text { Relevant } \\
\text { family history }\end{array}$ & $\begin{array}{l}\text { GD1 (sister), AD (mother), PD (father, paternal } \\
\text { grandmother, and first maternal cousin once } \\
\text { removed), reported DLB (paternal aunt), } \\
\text { reported FTD (maternal uncle), and dementia } \\
\text { (maternal aunt, maternal uncle) }\end{array}$ & None & $\begin{array}{l}\text { GD1 and PD (daughter, GBA compound } \\
\text { heterozygous N370S/P236T) and probable } \\
\text { bipolar disorder (son) }\end{array}$ \\
\hline $\begin{array}{l}\text { Motor } \\
\text { examination }\end{array}$ & $\begin{array}{l}\text { Diffuse wasting of limb muscles. } \\
\text { Fasciculations in the thoracic paraspinals and } \\
\text { limb muscles. Severe weakness on foot } \\
\text { dorsiflexion and great toe extension. Absent } \\
\text { DTRs in the UE, 3+ at the knees, 1+ at the } \\
\text { ankles. Extensor plantar response on the left }\end{array}$ & $\begin{array}{l}\text { Weak facial and tongue muscles, } \\
\text { questionable tongue fasciculations, and } \\
\text { positive jaw jerk reflex. No limb atrophy. Full } \\
\text { muscle power except for } 4 / 5 \text { in the deltoids. } \\
\text { Limb hyperreflexia. Bilateral extensor plantar } \\
\text { response }\end{array}$ & Mixed UMN and LMN findings \\
\hline $\begin{array}{l}\text { Other } \\
\text { neurologic } \\
\text { findings }\end{array}$ & $\begin{array}{l}\text { Mild cognitive impairment. Moderate facial } \\
\text { masking. Fine action hand tremor. No } \\
\text { parkinsonism. Reduced sensation in feet }\end{array}$ & Hoarseness, dysarthria, and slowed speech & No noted parkinsonism \\
\hline Neuroimaging & $\begin{array}{l}\text { Brain MRI: normal. Total spine MRI: mild } \\
\text { degenerative changes of the vertebral } \\
\text { column. Mild diffuse atrophy of the thoracic } \\
\text { spinal cord and conus }\end{array}$ & Brain MRI: normal. Cervical CT scan: normal & $\begin{array}{l}\text { Lumbar MRI: evident wasting of the } \\
\text { posterior paraspinal muscles. Multilevel } \\
\text { disc degeneration. Old vertebral fractures. } \\
\text { Mild L3-L4 spinal stenosis }\end{array}$ \\
\hline NCS/EMG & $\begin{array}{l}\text { Acute and chronic neurogenic changes in } \\
\text { proximal and distal muscles of } 3 \text { limbs and in } \\
\text { thoracic paraspinal muscles. Mild length- } \\
\text { dependent sensory polyneuropathy }\end{array}$ & Few distal fibrillations & $\begin{array}{l}\text { Consistent with typical ALS (full report not } \\
\text { available) }\end{array}$ \\
\hline $\begin{array}{l}\text { ALS genetic } \\
\text { analysis }\end{array}$ & Heterozygous c.1129C>G SQSTM1 & NA & NA \\
\hline ALS therapy & Riluzole & NA & BiPAP \\
\hline
\end{tabular}

The allele frequency (AF) of N370S present in case 1, case 2, and the daughter of case 3 was 0.003 in the French-Canadian cohort (similar to the $\mathrm{AF}$ found in European gnomAD controls) and 0.002176 in ALS Project MinE patients (similar to the AF found in ALS Project MinE controls). W378G, c.84dupG, and P236T found in case 1 , case 2 , and the daughter of case 3 , respectively, were not present in any of the ALS cohorts.

\section{Discussion}

Although the co-occurrence of GD1 with PD and the increased risk of PD among GBA mutation carriers are well established, the association of GD1 with ALS is rare. ${ }^{1}$ Of interest, 2 of 3 ALS cases reported here (1 patient with GD1 and 1 obligate GBA mutation carrier) have a family history of PD. Neurodegeneration in PD and ALS results from several shared mechanisms, including lysosomal dysfunction. ${ }^{3,4}$ Furthermore, a complex overlap between parkinsonian and motor neuron syndromes has long been appreciated with parkinsonism and ALS co-occurring within families or even within an individual patient. A genetic basis may underlie some cases of parkinsonism and ALS overlap, most notably nucleotide repeats in C9orf72 or ATXN2. ${ }^{910}$ Rare cases with both parkinsonism and ALS have been reported with mutations in DJ-1, ${ }^{11}$ TARDBP, ${ }^{12}$ or $A N G .^{13}$

One of the patients with ALS reported here (case 1) had GD1 due to W378G and N370S GBA mutations. N370S is one of 
Table 2 GBA Variants Identified in the Montreal FrenchCanadian ALS Cohort

\begin{tabular}{lllll}
\hline Variant & dbSNP ID & No. of carriers & AF & AF in gnomAD \\
\hline S52L & & 1 & 0.003 & $9 \times 10^{-6}$ \\
\hline E326K & rs2230288 & 3 & 0.009 & 0.012 \\
\hline T369M & rs75548401 & 3 & 0.009 & 0.009 \\
\hline N370S & rs76763715 & 1 & 0.003 & 0.002
\end{tabular}

Abbreviations: $\mathrm{AF}=$ allele frequency; $\mathrm{ALS}=$ amyotrophic lateral sclerosis = $\mathrm{dbSNP}=$ single nucleotide polymorphism database identification number; gnomAD = Genome Aggregation Database.

${ }^{a}$ Compared with European population controls.

the most frequent GBA mutations reported to be associated with increased PD risk. ${ }^{1}$ W378G is a French-Canadian founder GBA mutation more recently linked to GD1 and synucleinopathies when found in compound heterozygosity with N370S. ${ }^{14}$ Although case 1 did not have PD, there was a family history of PD and reported DLB (figure e-1, links.lww.com/NXG/A428). He was found to have a variant of uncertain significance in SQSTM1, but it did not segregate with the various neurodegenerative diseases in his family and therefore was not considered pathogenic. The increased risk of synucleinopathies with W378G and N370S raises the possibility of a synucleinopathy mimicking ALS in case 1 and possibly case 3. Lewy pathology can accompany typical MND pathology in patients with co-occurrence of ALS and parkinsonism ${ }^{15}$ and sometimes in patients with ALS without clinical parkinsonism. ${ }^{16}$ However, we did not find any definitive reports in the literature of Lewy pathology occurring in isolation (i.e., in the absence of MND pathology in both the brain and spinal cord) in patients presenting clinically with only ALS, without parkinsonian features. Yet, we cannot fully eliminate this possibility because we have no autopsy data for our patients.

Limitations of our study include the lack of neuropathologic data and lack of genetic data for ALS-related genes in 2 cases. In addition, genetic analyses only included exons 1-9 of the GBA gene and thus potentially excluded some GBA variants. This likely had a minimal effect on our results because mutations in the excluded exons in Europeans are rare. ${ }^{17}$ Identification of complex alleles was also limited with our genotyping methods.

Our analyses of GBA variants among 4,653 patients with ALS and 1,832 controls did not support heterozygosity for a GBA variant (i.e., 1 mutant GBA allele) as a risk factor for ALS. In contrast, a strong association between GBA variants and PD was previously demonstrated in a study of 5,691 patients with PD and 4,898 controls. ${ }^{18}$ Co-occurrence of GD1 (i.e., 2 mutant GBA alleles) and ALS in our reported cases could be coincidental; however, a previous report of ALS in a patient with type $3 \mathrm{GD}^{6}$ and the existence of common pathogenic pathways shared by GD and ALS suggest that GD could influence ALS risk. The association between GD1 and PD began with a suggestion from case reports, but definitive proof was obtained from a study of over 400 patients with GD. ${ }^{19}$ Considering that ALS is approximately one hundred times less prevalent than $\mathrm{PD}$, we expect that examination of much larger numbers of GD patients will be required to elucidate whether indeed there is a link between ALS and GD.

\section{Acknowledgment}

The authors thank the patients, the participants in each of the cohorts, the Project MinE GWAS Consortium, and the families for their involvement.

\section{Study Funding}

L.V. Kalia received support from Canadian Institutes of Health Research (CIHR) Clinician Scientist Award (MC2-157081). P.A. Dion received support from ALS Canada-Brain Canada Hudson Translational team grant and Radala Foundation. E.A. Rogaeva received support from ALS Canada. M. Zhang received support from Shanghai Pujiang Program (19PJ1410300) and Fundamental Research Funds for the Central Universities. Z. Gan-Or received support from Fonds de recherche du Québec-Santé (FRQS) Chercheurs-Boursiers Award, Parkinson Quebec, and Parkinson Canada Young Investigator Award.

\section{Disclosure}

L.M. Oliveira received funding for travel from Medtronic. T. Rastin has no disclosures. G.A.M. Nimmo received honoraria from Pfizer and Shire/Takeda and received consulting fees from Shire/Takeda. J.P. Ross received a doctoral student fellowship from the ALS Society of Canada and currently receives a Canadian Institutes of Health Research Frederick Banting \& Charles Best Canada Graduate Scholarship (FRN 159279). P.A. Dion received funding from the International Essential Tremor Foundation and currently receives funding from ALS Canada, Brain Canada, and Radala Foundation. M. Zhang, D.-L. Nevay, D. Arkadir, and M. Gotkine have no disclosures. C. Barnett has been a consultant for Akcea, Takeda, and Alexion and received research grants from Octapharma and Grifols. C.L. Shoesmith serves as scientific advisory board member for Mitsubishi Tanabe Pharma Canada, serves as DSMB member for Orion, and serves as site principal investigator for clinical trials run by Biogen and AL-S Pharma. A. Zimran receives honoraria from Pfizer, Takeda, and BioEvents, receives consulting fees from Takeda, Prevail Therapeutics, Avrobio, and Insightec, and receives research grants from Sanofi/Genzyme, Takeda, Pfizer, and Centogene. E.A. Rogaeva, L. Zinman, and G.A. Rouleau have no disclosures. Z. Gan-Or received consulting fees from Denali, Genzyme (now Sanofi), Inception Sciences (now Ventus), Idorsia, Lysosomal Therapeutics Inc., Prevail Therapeutics, Deerfield, Neuron23, and Handl Therapeutics. D. Amato received honoraria, served on advisory board, and received funding for travel from Actelion, Pfizer, Sanofi/Genzyme, and Shire/Takeda. L.V. Kalia served as site principal investigator for clinical trials run by ApoPharma, received educational grants from Allergan, and received honoraria from the NIH, Pfizer, and Shire/Takeda. Go to Neurology.org/NG for full disclosures. 
Table 3 GBA Variants Identified in Patients With ALS or Controls From the Project MinE Data Set ${ }^{7,8}$

\begin{tabular}{|c|c|c|c|c|c|}
\hline Variant & ID & AF cases & AF controls & $A F$ in gnomAD (WGS) $)^{20}$ & $A F$ in gnomAD (WES) $)^{20}$ \\
\hline R463P & chr1:155204986:C:G & 0.0001145 & 0 & NA & NA \\
\hline D453V & chr1:155205016:T:A; rs771744004 & 0.0001145 & 0.0002729 & NA & $2.03282 \mathrm{e}-05$ \\
\hline D453H & chr1:155205017:C:G; rs779958429 & 0.0001145 & 0.0002729 & NA & $2.03283 e-05$ \\
\hline D443N & chr1:155205047:C:T; rs75671029 & 0 & 0.0002729 & 0.00219709 & 0.000512291 \\
\hline K425T & chr1:155205100:T:G & 0.0001145 & 0 & NA & NA \\
\hline D409H & chr1:155205518:C:G; rs1064651 & 0.0001145 & 0 & 0.00025895 & 0.000126416 \\
\hline R395C & chr1:155205560:G:A & 0.0001145 & 0 & NA & $4.06128 \mathrm{e}-06$ \\
\hline E388K & chr1:155205581:C:T; rs149171124 & 0.0005726 & 0.0005459 & $3.23039 \mathrm{e}-05$ & 0.000178674 \\
\hline N370S & chr1:155205634:T:C; rs76763715 & 0.002176 & 0.002186 & 0.0016507 & 0.00232286 \\
\hline R359P & chr1:155206067:C:G & 0.0001145 & 0 & NA & NA \\
\hline Q350H & chr1:155206093:C:G; rs761681845 & 0.000229 & 0 & $3.2329 \mathrm{e}-05$ & $2.03041 \mathrm{e}-05$ \\
\hline R329C & chr1:155206158:G:A; rs374306700 & 0.0001145 & 0 & NA & $1.21818 \mathrm{e}-05$ \\
\hline E326K & chr1:155206167:C:T; rs2230288 & 0.01649 & 0.01528 & 0.012828 & 0.0106732 \\
\hline A269T & chr1:155207209:C:T; rs368425393 & 0 & 0 & NA & $2.03287 e-05$ \\
\hline T267I & chr1:155207214:G:A; rs199628072 & 0.0001145 & 0 & 0.000129232 & $5.2852 \mathrm{e}-05$ \\
\hline R262H & chr1:155207229:C:T; rs140955685 & 0.0001145 & 0.0008188 & 0.000290698 & $8.94382 \mathrm{e}-05$ \\
\hline F259L & chr1:155207237:G:T & 0.0001145 & 0 & NA & NA \\
\hline H255Q & chr1:155207249:A:C; rs367968666 & 0.0003436 & 0 & $6.45995 \mathrm{e}-05$ & 0.000239828 \\
\hline S237F & chr1:155207304:G:A; rs755512507 & 0 & 0.0002734 & NA & $8.12942 \mathrm{e}-06$ \\
\hline F216Y & chr1:155207367:A:T; rs74500255 & 0 & 0.0002731 & $3.2306 \mathrm{e}-05$ & $1.22561 \mathrm{e}-05$ \\
\hline Y212H & chr1:155207935:A:G; rs121908300 & 0.0001145 & 0 & NA & $4.06062 \mathrm{e}-06$ \\
\hline D140H & chr1:155208361:C:G; rs147138516 & 0.001038 & 0.0008228 & $9.72321 \mathrm{e}-05$ & 0.000138342 \\
\hline R131C & chr1:155208388:G:A; rs398123530 & 0.0001147 & 0 & NA & $4.0658 \mathrm{e}-06$ \\
\hline$c .307+1 G>T$ & chr1:155209676:C:A & 0.0001145 & 0 & NA & NA \\
\hline T63R & chr1:155209679:G:C & 0.0001145 & 0 & NA & NA \\
\hline R44C & chr1:155209737:G:A; rs1141812 & 0 & 0.0002731 & $6.46078 \mathrm{e}-05$ & $8.53187 e-05$ \\
\hline R39C & chr1:155209752:G:A; rs146774384 & 0.0001145 & 0 & $9.69681 \mathrm{e}-05$ & $9.34336 \mathrm{e}-05$ \\
\hline Y22F & chr1:155209802:T:A & 0.0001145 & 0 & NA & NA \\
\hline C18* & chr1:155209813:G:T & 0.0001145 & 0 & NA & NA \\
\hline V15M & chr1:155209824:C:T & 0 & 0.0002729 & NA & NA \\
\hline Q(-8)R & chr1:155210441:T:C & 0.000229 & 0.0002729 & NA & NA \\
\hline$V(-22) E$ & chr1:155210483:A:T & 0 & 0.0002729 & NA & NA \\
\hline$L(-25) S$ & chr1:155210492:A:G; rs1141802 & 0.0001145 & 0 & $6.45911 \mathrm{e}-05$ & 3.66202e-05 \\
\hline$K(-27) R$ & chr1:155210498:T:C; rs150466109 & 0.0001145 & 0.0002729 & 0.0224392 & 0.00544965 \\
\hline$C(-29) S$ & chr1:155210505:A:T & 0.0001145 & 0 & NA & NA \\
\hline
\end{tabular}

Abbreviations: $A F=$ allele frequency; $A L S=$ amyotrophic lateral sclerosis; ID = variant identification; gnomAD = Genome Aggregation Database; $N A=$ not available; WES = whole-exome sequencing; WGS = whole-genome sequencing. 


\section{Publication History}

Received by Neurology: Genetics February 20, 2021. Accepted in final form April 23, 2021.

Appendix Authors

\begin{tabular}{|c|c|c|}
\hline Name & Location & Contribution \\
\hline $\begin{array}{l}\text { Lais M. } \\
\text { Oliveira, MD }\end{array}$ & $\begin{array}{l}\text { Krembil Research Institute, } \\
\text { Toronto Western Hospital, } \\
\text { University Health Network, } \\
\text { Ontario, Canada }\end{array}$ & $\begin{array}{l}\text { Major role in the acquisition } \\
\text { of data; analysis or } \\
\text { interpretation of data; and } \\
\text { drafting of the manuscript }\end{array}$ \\
\hline $\begin{array}{l}\text { Tara Rastin, } \\
\text { MD }\end{array}$ & $\begin{array}{l}\text { Djavad Mowafaghian Centre } \\
\text { for Brain Health, Division of } \\
\text { Neurology, Department of } \\
\text { Medicine, University of British } \\
\text { Columbia, Vancouver, Canada }\end{array}$ & $\begin{array}{l}\text { Major role in the acquisition } \\
\text { of data; analysis or } \\
\text { interpretation of data; and } \\
\text { drafting of the manuscript }\end{array}$ \\
\hline $\begin{array}{l}\text { Graeme } \\
\text { A.M. } \\
\text { Nimmo, } \\
\text { MBBS, MSc }\end{array}$ & $\begin{array}{l}\text { The Fred A. Litwin Family } \\
\text { Centre in Genetic Medicine, } \\
\text { University Health Network \& } \\
\text { Mount Sinai Hospital, } \\
\text { Toronto, Ontario, Canada }\end{array}$ & $\begin{array}{l}\text { Major role in the acquisition } \\
\text { of data; analysis or } \\
\text { interpretation of data; and } \\
\text { revision of the manuscript } \\
\text { for content }\end{array}$ \\
\hline
\end{tabular}

Jay P. Ross, Department of Human Major role in the acquisition BSC Genetics, McGill University, Montreal, Quebec, Canada; interpretation of data; and Montreal Neurological revision of the manuscript Institute and Hospital, McGill for content University, Quebec, Canada

\begin{tabular}{|c|c|c|}
\hline $\begin{array}{l}\text { Patrick A. } \\
\text { Dion, PhD }\end{array}$ & $\begin{array}{l}\text { Department of Neurology } \\
\text { and Neurosurgery, McGill } \\
\text { University, Montreal, } \\
\text { Quebec, Canada }\end{array}$ & $\begin{array}{l}\text { Major role in the acquisition of } \\
\text { data; analysis or interpretation } \\
\text { of data; and revision of the } \\
\text { manuscript for content }\end{array}$ \\
\hline $\begin{array}{l}\text { Ming Zhang, } \\
\text { PhD }\end{array}$ & $\begin{array}{l}\text { Shanghai First Rehabilitation } \\
\text { Hospital, School of Medicine, } \\
\text { Tongji University, China; Tanz } \\
\text { Centre for Research in } \\
\text { Neurodegenerative Diseases, } \\
\text { University of Toronto, Ontario, } \\
\text { Canada; Clinical Center for } \\
\text { Brain and Spinal Cord } \\
\text { Research, Tongji University, } \\
\text { Shanghai, China; Institute for } \\
\text { Advanced Study, Tongji } \\
\text { University, Shanghai, China }\end{array}$ & $\begin{array}{l}\text { Major role in the acquisition } \\
\text { of data; analysis or } \\
\text { interpretation of data; and } \\
\text { revision of the manuscript } \\
\text { for content }\end{array}$ \\
\hline $\begin{array}{l}\text { Dayna-Lynn } \\
\text { Nevay, MSc, } \\
\text { CCGC }\end{array}$ & $\begin{array}{l}\text { The Fred A. Litwin Family } \\
\text { Centre in Genetic Medicine, } \\
\text { University Health Network \& } \\
\text { Mount Sinai Hospital, } \\
\text { Toronto, Ontario, Canada }\end{array}$ & $\begin{array}{l}\text { Major role in the acquisition } \\
\text { of data; analysis or } \\
\text { interpretation of data; and } \\
\text { revision of the manuscript } \\
\text { for content }\end{array}$ \\
\hline $\begin{array}{l}\text { David } \\
\text { Arkadir, MD, } \\
\text { PhD }\end{array}$ & $\begin{array}{l}\text { Faculty of Medicine, Hebrew } \\
\text { University of Jerusalem, Israel; } \\
\text { Department of Neurology, } \\
\text { Hadassah Medical Center, } \\
\text { Jerusalem, Israel }\end{array}$ & $\begin{array}{l}\text { Major role in the acquisition } \\
\text { of data; analysis or } \\
\text { interpretation of data; and } \\
\text { revision of the manuscript } \\
\text { for content }\end{array}$ \\
\hline $\begin{array}{l}\text { Marc } \\
\text { Gotkine, } \\
\text { MBBS }\end{array}$ & $\begin{array}{l}\text { Faculty of Medicine, Hebrew } \\
\text { University of Jerusalem, Israel; } \\
\text { Department of Neurology, } \\
\text { Hadassah Medical Center, } \\
\text { Jerusalem, Israel }\end{array}$ & $\begin{array}{l}\text { Major role in the acquisition } \\
\text { of data; analysis or } \\
\text { interpretation of data; and } \\
\text { revision of the manuscript } \\
\text { for content }\end{array}$ \\
\hline $\begin{array}{l}\text { Carolina } \\
\text { Barnett, MD, } \\
\text { PhD }\end{array}$ & $\begin{array}{l}\text { Ellen \& Martin Prosserman } \\
\text { Centre for Neuromuscular } \\
\text { Diseases, Division of } \\
\text { Neurology, Department of } \\
\text { Medicine, Toronto General } \\
\text { Hospital, University Health } \\
\text { Network, University of } \\
\text { Toronto, Ontario, Canada }\end{array}$ & $\begin{array}{l}\text { Major role in the acquisition } \\
\text { of data; analysis or } \\
\text { interpretation of data; and } \\
\text { revision of the manuscript } \\
\text { for content }\end{array}$ \\
\hline
\end{tabular}

Appendix (continued)

\begin{tabular}{lll}
\hline Name & Location & Contribution \\
\hline $\begin{array}{l}\text { Christen L. } \\
\text { Shoesmith, } \\
\text { MD }\end{array}$ & $\begin{array}{l}\text { London Health Sciences } \\
\text { Centre, London, Ontario, } \\
\text { Canada }\end{array}$ & $\begin{array}{l}\text { Major role in the acquisition } \\
\text { of data; analysis or } \\
\text { interpretation of data; and } \\
\text { revision of the manuscript } \\
\text { for content }\end{array}$ \\
\hline $\begin{array}{l}\text { Ari Zimran, } \\
\text { MD }\end{array}$ & $\begin{array}{l}\text { Gaucher Unit, Shaare Zedek } \\
\text { Medical Center, Hebrew } \\
\text { University and Hadassah } \\
\text { Medical School, Jerusalem, } \\
\text { Israel }\end{array}$ & $\begin{array}{l}\text { Major role in the acquisition } \\
\text { of data; analysis or } \\
\text { interpretation of data; and } \\
\text { revision of the manuscript } \\
\text { for content }\end{array}$ \\
\hline
\end{tabular}

Ekaterina A. Tanz Centre for Research in Major role in the acquisition Rogaeva, Neurodegenerative of data; analysis or

PhD Diseases, University of interpretation of data; and Toronto, Ontario, Canada revision of the manuscript for content

\begin{tabular}{lll}
\hline Lorne & Sunnybrook Health Sciences & Major role in the acquisition \\
Zinman, MD, & Centre, University of & of data; analysis or \\
MSc & Toronto, Ontario, Canada & $\begin{array}{l}\text { interpretation of data; and } \\
\text { revision of the manuscript } \\
\end{array}$ \\
& & for content
\end{tabular}

Guy A. Department of Neurology Major role in the acquisition

Rouleau, and Neurosurgery, McGill of data; analysis or

MD, PhD University, Montreal, interpretation of data; and Quebec, Canada revision of the manuscript for content

\begin{tabular}{lll}
\hline $\begin{array}{l}\text { Ziv Gan-Or, } \\
\text { MD, PhD }\end{array}$ & $\begin{array}{l}\text { Montreal Neurological } \\
\text { Institute, McGill University, } \\
\text { Quebec, Canada; } \\
\text { Department of Human } \\
\text { Genetics, McGill } \\
\text { University, Montreal, } \\
\text { Quebec, Canada; } \\
\text { Department of Neurology } \\
\text { and Neurosurgery, McGill } \\
\text { University, Montreal, } \\
\text { Quebec, Canada }\end{array}$ & $\begin{array}{l}\text { Major role in the acquisition } \\
\text { of data; analysis or } \\
\text { revision of the manuscript } \\
\text { for content }\end{array}$ \\
& \\
Dominick & $\begin{array}{l}\text { Mark Freedman and Judy } \\
\text { Amato, MD }\end{array}$ & \\
& $\begin{array}{l}\text { Jacobs Program for Gaucher } \\
\text { Disease, Mount Sinai } \\
\text { Hospital, Toronto, Ontario, } \\
\text { Canada }\end{array}$ & $\begin{array}{l}\text { Study concept or design; } \\
\text { major role in the acquisition } \\
\text { of data; analysis or } \\
\text { interpretation of data; and } \\
\text { revision of the manuscript } \\
\text { for content }\end{array}$ \\
& & for content
\end{tabular}

Lorraine V. Krembil Research Institute,

Kalia, MD, Toronto Western Hospital,

PhD University Health Network,

Ontario, Canada; Tanz

Centre for Research in

Neurodegenerative

Diseases, University of

Toronto, Ontario, Canada;

Mark Freedman and Judy

Jacobs Program for Gaucher

Disease, Mount Sinai

Hospital, Toronto, Ontario,

Canada; Division of

Neurology, Department of

Medicine, University of

Toronto, Ontario, Canada;

Edmond J. Safra Program in

Parkinson's Disease and the

Morton and Gloria Shulman

Movement Disorders Clinic,

Division of Neurology,

Department of Medicine,

Toronto Western Hospital,

University Health Network,

Ontario, Canada
Study concept or design; major role in the acquisition of data; analysis or interpretation of data; and revision of the manuscript for content 


\section{References}

1. Sidransky E, Lopez G. The link between the GBA gene and parkinsonism. Lancet Neurol. 2012;11(11):986-998.

2. Alcalay RN, Mallett V, Vanderperre B, et al. SMPD1 mutations, activity, and $\alpha$-synuclein accumulation in Parkinson's disease. Mov Disord. 2019;34(4):526-535.

3. Senkevich K, Gan-Or Z. Autophagy lysosomal pathway dysfunction in Parkinson's disease; evidence from human genetics. Parkinsonism Relat Disord. 2020;73:60-71.

4. Hardiman O, Al-Chalabi A, Chio A, et al. Amyotrophic lateral sclerosis. Nat Rev Dis Primer. 2017;3(1):1-19.

5. Beer AM, Cooper-Knock J, Fletcher S, Brown-Wright SH, Nandakumar TP, Shaw PJ. Case report of concurrent Fabry disease and amyotrophic lateral sclerosis supports a common pathway of pathogenesis. Amyotroph Lateral Scler Front Degener. 2016;17(78):614-616.

6. Pozzilli V, Giona F, Ceccanti M, et al. A case of motor neuron involvement in Gaucher disease. Mol Genet Metab Rep. 2019;21:100540.

7. van der Spek RAA, van Rheenen W, Pulit SL, et al. The project MinE databrowser: bringing large-scale whole-genome sequencing in ALS to researchers and the public. Amyotroph Lateral Scler Front Degener. 2019;20(5-6):432-440.

8. Project MinE ALS Sequencing Consortium. Project MinE: study design and pilot analyses of a large-scale whole-genome sequencing study in amyotrophic lateral sclerosis. Eur J Hum Genet. 2018;26(10):1537-1546.

9. Bourinaris T, Houlden $\mathrm{H}$. C9orf72 and its relevance in parkinsonism and movement disorders: a comprehensive review of the literature. Mov Disord Clin Pract. 2018;5(6): 575-585.

10. Braga-Neto P, Pedroso JL, Felício AC, et al. SCA2 presenting as an ataxiaparkinsonism-motor neuron disease syndrome. Arq Neuropsiquiatr. 2011;69(2B): 405-406.
11. Hanagasi HA, Giri A, Kartal E, et al. A novel homozygous DJ1 mutation causes parkinsonism and ALS in a Turkish family. Parkinsonism Relat Disord. 2016;29: 117-120.

12. Mosca L, Lunetta C, Tarlarini C, et al. Wide phenotypic spectrum of the TARDBP gene: homozygosity of A382T mutation in a patient presenting with amyotrophic lateral sclerosis, Parkinson's disease, and frontotemporal lobar degeneration, and in neurologically healthy subject. Neurobiol Aging. 2012;33(8):1846.e1-1846.e4.

13. van Es MA, Diekstra FP, Veldink JH, et al. A case of ALS-FTD in a large FALS pedigree with a K17I ANG mutation. Neurology. 2009;72(3):287-288.

14. Ruskey JA, Zhou S, Santiago R, et al. The GBA p.Trp378Gly mutation is a probable French-Canadian founder mutation causing Gaucher disease and synucleinopathies. Clin Genet. 2018;94(3-4):339-345.

15. Klos KJ, Josephs KA, Parisi JE, Dickson DW. Alpha-synuclein immunohistochemistry in two cases of co-occurring idiopathic Parkinson's disease and motor neuron disease. Mov Disord. 2005;20(11):1515-1520.

16. Ayaki $\mathrm{T}$, Ito $\mathrm{H}$, Komure $\mathrm{O}$, et al. Multiple proteinopathies in familial ALS cases with optineurin mutations. J Neuropathol Exp Neurol. 2018;77(2):128-138.

17. Krohn L, Ruskey JA, Rudakou U, et al. GBA variants in REM sleep behavior disorder: a multicenter study. Neurology. 2020;95(8):e1008-e1016.

18. Sidransky E, Nalls MA, Aasly JO, et al. Multicenter analysis of glucocerebrosidase mutations in Parkinson's disease. N Engl J Med. 2009;361(17):1651-1661.

19. Alcalay RN, Dinur T, Quinn T, et al. Comparison of Parkinson risk in Ashkenazi Jewish patients with Gaucher disease and GBA heterozygotes. JAMA Neurol. 2014; $71(6): 752-757$.

20. Karczewski KJ, Francioli LC, Tiao G, et al. The mutational constraint spectrum quantified from variation in 141,456 humans. Nature. 2020;581(7809): 434-443. 


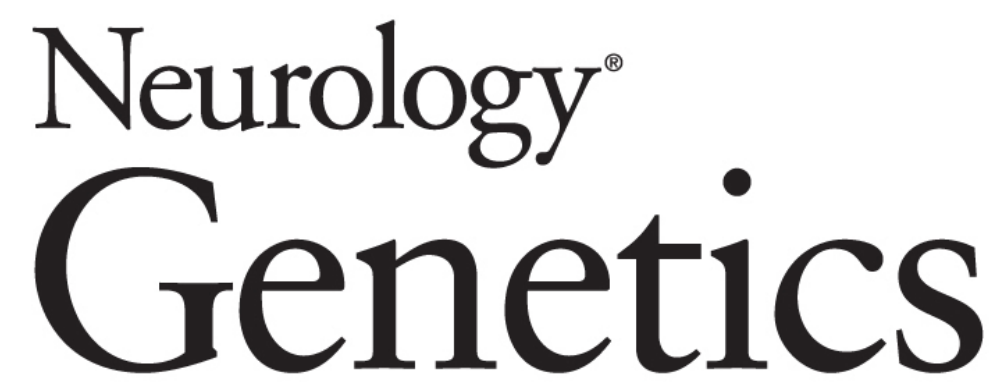

Occurrence of Amyotrophic Lateral Sclerosis in Type 1 Gaucher Disease Lais M. Oliveira, Tara Rastin, Graeme A.M. Nimmo, et al. Neurol Genet 2021;7;

DOI 10.1212/NXG.0000000000000600

This information is current as of May 18, 2021

Neurol Genet is an official journal of the American Academy of Neurology. Published since April 2015, it is an open-access, online-only, continuous publication journal. Copyright Copyright ( 2021 The Author(s). Published by Wolters Kluwer Health, Inc. on behalf of the American Academy of Neurology.. All rights reserved. Online ISSN: 2376-7839.

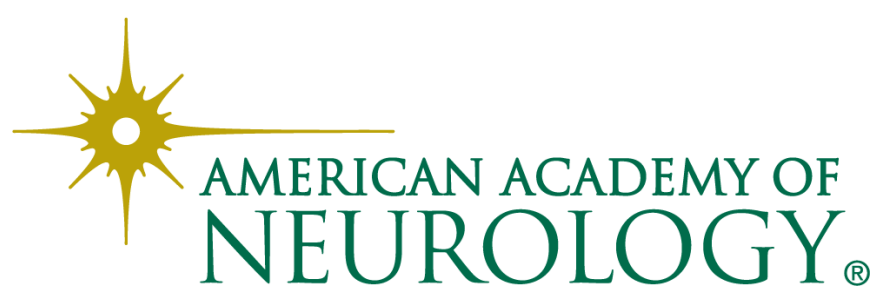




\section{Updated Information \& Services}

References

Subspecialty Collections

Permissions \& Licensing

Reprints including high resolution figures, can be found at:

http://ng.neurology.org/content/7/4/e600.full.html

This article cites 20 articles, 0 of which you can access for free at: http://ng.neurology.org/content/7/4/e600.full.html\#\#ref-list-1

This article, along with others on similar topics, appears in the following collection(s):

Amyotrophic lateral sclerosis

http://ng.neurology.org//cgi/collection/amyotrophic_lateral_sclerosis_ Association studies in genetics

http://ng.neurology.org//cgi/collection/association_studies_in_genetics Hematologic

http://ng.neurology.org//cgi/collection/hematologic

Metabolic disease (inherited)

http://ng.neurology.org//cgi/collection/metabolic_disease_inherited

Parkinson's disease/Parkinsonism

http://ng.neurology.org//cgi/collection/parkinsons_disease_parkinsonis $\mathrm{m}$

Information about reproducing this article in parts (figures,tables) or in its entirety can be found online at:

http://ng.neurology.org/misc/about.xhtml\#permissions

Information about ordering reprints can be found online:

http://ng.neurology.org/misc/addir.xhtml\#reprintsus

Neurol Genet is an official journal of the American Academy of Neurology. Published since April 2015, it is an open-access, online-only, continuous publication journal. Copyright Copyright $\odot 2021$ The Author(s). Published by Wolters Kluwer Health, Inc. on behalf of the American Academy of Neurology.. All rights reserved. Online ISSN: 2376-7839.

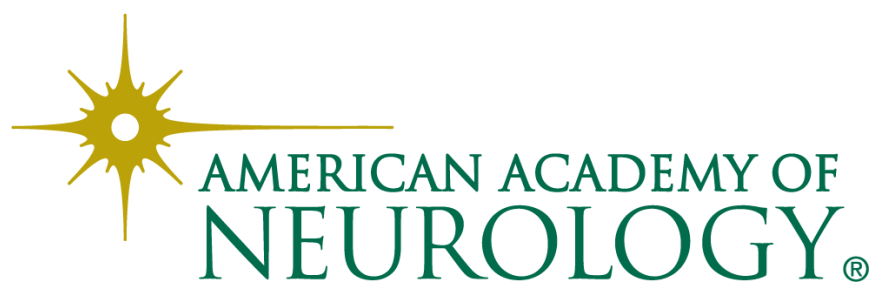

